Article

\title{
Towards Transgressive Learning through Ontological Politics: Answering the "Call of the Mountain" in a Colombian Network of Sustainability
}

\author{
Martha Chaves ${ }^{1}$, Thomas Macintyre ${ }^{2, *}$, Gerard Verschoor ${ }^{3}$ and Arjen E. J. Wals ${ }^{4}$ \\ 1 Sociology of Development and Change Group, Wageningen University, P.O. Box 8130, 6706 KN Wageningen, \\ The Netherlands; marthacecilia.chaves@gmail.com \\ 2 MINGAS in Transition Research Group, Calle 8 \# 16-218 Rozo, Palmira, Colombia \\ 3 Sociology of Development and Change Group, Wageningen University, Hollandseweg 1, $6706 \mathrm{KN}$ \\ Wageningen, The Netherlands; Gerard.Verschoor@wur.nl \\ 4 Education and Competence Studies Group (ECS), Wageningen University, Hollandseweg 1, $6706 \mathrm{KN}$ \\ Wageningen, The Netherlands; arjen.wals@wur.nl \\ * Correspondence: Thomas.macintyre@gmail.com; Tel.: +57-315-5042436
}

Academic Editor: Helmut Haberl

Received: 6 October 2016; Accepted: 16 December 2016; Published: 24 December 2016

\begin{abstract}
In line with the increasing calls for more transformative and transgressive learning in the context of sustainability studies, this article explores how encounters between different ontologies can lead to socio-ecological sustainability. With the dominant one-world universe increasingly being questioned by those who advocate the existence of many worlds - a so-called pluriverse- there lays the possibility of not only imagining other human-nature realities, but also engaging with them in practice. Moving towards an understanding of what happens when a multiplicity of worlds encounter one another, however, entails a sensitivity to the negotiations between often competing ontologies-or ontological politics. Based on an ethnographic methodology and narrative methods, data were collected from two consecutive intercultural gatherings called El Llamado de la Montaña (The Call of the Mountain), which take place for five days every year in different parts of Colombia. By actively participating in these gatherings of multiplicity, which address complex socio-ecological challenges such as food sovereignty and defence of territory, results show how encounters between different ontologies can result in transformative and potentially transgressive learning in terms of disrupting stubborn routines, norms and hegemonic powers which tend to accelerate unsustainability. Although we argue that a fundamental part of the wicked sustainability puzzle lies in supporting more relational ontologies, we note that such learning environments also lead to conflicts through inflexibility and $(\mathrm{ab})$ use of power which must be addressed if sustained socio-ecological learning is to take place.
\end{abstract}

Keywords: ontological politics; transformative learning; transgressive learning; sustainability; Colombia; narrative methods

\section{Introduction to Other Realities}

"We are the new seeds that sprout from the earth. We have been called upon to restore the times of our peoples, and we are going towards the call of the mountain, from whose veins sprout great memories of new dawns in which to live. And we stand up in a silent way, because we recognize the silence of the sun and we know how to listen to the moon. It is the time of the new beings, and the air will give us the strength to carry this great message." (First part of a song written by Lorenzo Muelas Tombé, an Indigenous Misak youth who helped organize the 2015 gathering of the Call of the Mountain) 
High up in the Andean mountains of Southern Colombia, in the Indigenous territory of Misak, a sacred walk is taking place. Led by the Misak people, and followed by abuelos (elders), ecovillagers, Hare Krishna, urban intellectuals, and foreigners, this diverse collection of people are walking towards the pueblo of Silvia to "activate and heal the bond with one's own territory ... and as a collective prayer for life and for peace". (Ana María, Council of Women Elders of Colombia [1]). Everyone is holding a seedling in their hands, and walking to the rhythm of the traditional Misak drums and flutes. Arriving to the pueblo, everyone boards a colorful (if dilapidated) chiva bus, which carries its motley crew to the agricultural development land of the Indigenous Misak University. After being received with the traditional fermented maize drink chicha, the group of over 300 people prepares to sembrar agua (plant water) through the reforestation of 2000 trees in a neighboring wetland. While the mamitas (women elders) are cooking a traditional soup called sancocho over an open fire (and remarking on the difficulty of making a tasty sancocho without meat as requested by the organizers), an animated group of abuelas, children, Hare Krishnas and ecovillagers are singing and chanting to the soup, while a human chain forms to efficiently move the seedlings to where they are to be planted. Under the animated discussion between Misak youth and permacultural experts about which variety of seedling should be planted where, and accompanied by a steady drizzle of rain, holes are dug, hands reach into the soil, and seedlings are given a new home. When the last seedling is rooted, everyone trudges back to the farmhouse to eat the sancocho, drink an agua panela (sugar cane tea) and celebrate. "Hermanos, thank you for helping us plant our water and for sharing in this collective effort" a Misak organizer cries aloud to everyone, who respond with a cheer. In all this excitement a little girl asks her mom: "why are we planting water? why are we singing to the soup?"

This research addresses ontological encounters entailed in bringing about socio-ecological sustainability. The addition of "socio-ecological" to sustainability is intentional, as much work done on sustainability nowadays tends to focus on economic sustainability, often without people and planet in mind. Adrian Parr [2] even suggests that sustainability has gradually been hijacked and neutered by neo-liberal economic interests. While economics inevitably is part of the sustainability puzzle, the need to pay full attention to the ecological boundaries within which both humans and non-humans will have to live together requires taking on board issues that vastly overflow the economic undercurrent that dominates the on-going sustainability discourse [3-5].

This emphasis is particularly prudent in a time when the hegemony of the development and globalization "projects" [6] are in crisis, with new narratives of human-nature relations emerging which propose fundamental changes in how we understand the world and its relations. This is nowhere more apparent than in the region of Latin America where counter-hegemonic movement at the political and social level are being witnessed. The new constitutions of Bolivia and Ecuador have respectively acknowledged a plurinational state and the rights of nature (both affronts to the notion of the modern state), while social movements combining Indigenous communities and environmental activists are gathering around endogenous concepts like buen vivir (the good life) which propose more biocentric, relational and communal relations [7].

The above examples provide a glimpse into the profound but difficult notion of different worlds living side by side in what some authors are calling the pluriverse [8-11]. Such coexistence of multiple worlds denotes a departure from the homogenizing and euphemistic idea of the "global village" [11], instead giving status to alternative ways of being in the world. These sub-altern alternatives, it has been argued, can provide a diversity of responses to the global crisis if only one would consider their knowledge to be equally valid [12]. Such a decolonial attitude fits into the greater sustainability transition discourses which call for radical cultural and institutional transformations to an "altogether different world" [13] (p. 138).

However, the question arises as to how alternative ways of being and knowing can contribute to addressing the sustainability challenges of our time [9]. This article is based on the premise that people learn more from each other when they are confronted by different realities-what exists, and our underlying assumptions of what is, what is not and what might be. When an urban environmentalist 
meets an ecovillager and an Indigenous person, all three expounding different understandings of what it means to plant a tree-or when a strictly vegetarian Hare Krishna devotee is confronted with an Indigenous Misak or Arhuaco who eats (wild) meat as part of their culture, there is the potential for clashes and conflicts, but also for new insights and understandings in what it means to live an environmentally and socially responsible life together with other people who do not necessarily share that reality. Such encounters have the potential to transform the way we learn from the world around us through challenging deeply held beliefs and habits [4]. This is based on the increasing recognition that more emancipatory forms of transformative learning can lead to far deeper and more meaningful engagement in sustainability issues than, for example, trying to change people's environmental behavior instrumentally through, for instance, persuasion, social marketing or by law [14].

Returning to the opening scene of this article-high up in the Andean mountains-we can see a description taken from El Llamado de la Montaña (The Call of the Mountain). Organised by the sustainability network C.A.S.A. Colombia [15], this yearly Colombian gathering brings together a diverse array of people, communities and projects for five days of communal living, in which participants exchange experiences on sustainable living while partaking in working councils, workshops, panel discussions, dances and other artistic pursuits. El Llamado, as the event is referred to, brings together Indigenous elders and businesspeople, urban permaculturalists and peasants, and Hare Krishna devotees and academics, to name just a few. The event is self-financed and self-organized, and has the aim of articulating and forging alliances between diverse grassroots movements in Colombia around pressing socio-ecological concerns such as food sovereignty, mega-mining, and post-conflict reconstruction. The interactions during the event represents an "environmentalism of everyday life" [16], where participants share social justice and environmental concerns through embodied practices during the event, often explicitly acknowledging and promoting the role of the non-human realm. From this yearly exercise of community and human-nature interaction, a central challenge has emerged in how to deal with encounters within and between a diversity of peoples, visions and knowledges. It has been recognized by event organizers that such encounters can promote innovative thinking and action when differences come together in a generative learning environment, yet it is also acknowledged as leading to conflict through misunderstandings, poor communication and other underlying issues.

\section{Transgressive Learning and the Ontological Politics of the Pluriverse}

Studying the challenges and opportunities of an "environmentalism of everyday life" can be done from a variety of perspectives. We approach these challenges and opportunities through a twofold strategy in which we combine an interest in ontological politics and the transgressive learning that may be obtained from this.

The concept of "ontological politics" originates from the so-called "ontological turn" in anthropology and science and technology studies $[17,18]$. The concept of ontology itself originally comes from philosophy, and involves the study of reality and questions related to the kind of entities that can be said to exist as well as the relations between them [19]. Importantly, the ontological turn assumes that there exist a multiplicity of realities or worlds [20-22]. Underlying this proposition is the argument that the reality we live in is one performed in a variety of practices [18], whereby reality does not precede the everyday practices in which we interact with "the world", but is rather shaped within those practices [23]. Since practices are multiple, so too are the realities they produce-hence, "if reality is done, then it is also multiple" [18] (p. 75). Therefore, multiple worlds or ontologies do not form a universe, but rather what William James called a "pluriverse" or a "multiverse" [24]. In this pluriverse, these different worlds or "ways of being" are partially connected, i.e., they are connected without implying that they share a common ontology [25].

Partial connections between different worlds or realities inevitably lead to ontological encounters. In these encounters, ontological disjunctures or misunderstandings are very likely to occur. Viveiros de Castro calls these situations occasions of "uncontrolled equivocation": "a type of communicative 
disjuncture where the interlocutors are not talking about the same thing, and do not know this" [26] (p. 9). Situations such as these (involving Indigenous taitas and abuelas, Hare Krishnas and ecovillagers) of course abound in the different Llamados de la Montaña which are the object of our study. We find these situations interesting - not for the clashes between different ways of being, but rather for the ontological politics that come with them; that is, the possibility that practices (and hence realities) might be changed for other ways of being that "could be" [17]. When deployed in the "transgressive" context of our own sustainability struggles, ontological encounters provide a treasure for learning that unsustainable realities are not destiny.

In the context of this article, then, we are interested in the dynamics that take place in the encounter and interaction between the different worlds or ontologies that meet in the micro-cosmos apparent in the Llamado de la Montaña. In particular, we focus on the power-saturated, "partially connected unfolding of worlds" [19] that are constantly becoming, giving rise to new ontologies through concrete relations and actions among persons, things, spirits, and deities. In these new "worlds in the making" transgressive learning results from the power-laden ontological interactions, interferences and blendings that are characteristic of complex socio-ecological settings.

Taking these affections (and the notion of the pluriverse) seriously, however, means addressing fundamental issues underlying power relations upheld through practices. Several social movements and theories of decolonialization acknowledge this and have been identified as a stream of emerging transgressive and transformative research and praxis in the sustainability sciences [27]. In this paper we will employ the emerging concept of transgressive learning in challenging the taken for granted, normalized status quo of global systemic dysfunction [28,29]. As a form of transformative learning, the concept focuses on uprooting structures of privilege and hegemonies of power through innovative strategies which foreground cognitive, epistemic, social and environmental justice, often through activism and normative interventions. While Mezirow's theory of Transformative learning [30] is often used to frame such discussions about the changes in values and worldviews needed to move towards a more sustainable world, its theory is mainly based on cognitive change at the level of the individual [27]. The emerging concept of transgressive theory attempts to take a more decolonial and transdisciplinary stance [31] building on such work as that of the critical pedagogy of Paolo Freire [32] in Latin America, and other strands such as reflexive social learning and capabilities theory, critical phenomenology, and socio-cultural and cultural historical activity theory [27]. Important for transgressive learning theory is recognizing that socio-technical transitions to sustainability do not come about easily because of lock-in mechanisms which maintain poverty and social injustices. To address this, transgressive learning posits that radical innovations instead occur in "niches" [33], in which the cultivation and productive utilization of multiplicity are necessary for transformative disruptions to emerge [4]. Put simply, people learn more from each other when they are different from each other, as this creates more space for reflection through disruption and dissonance [34]. However, it has also been emphasized that the tensions which arise between different ways of thinking are only productive when strong affects exist within the group [35], and the upscaling of these processes are dependent on external landscape developments putting pressure on dominant regimes so as to open windows of opportunity for niches to expand [33]. Transgressive learning therefore plays an important part of this paper as it represents a type of learning which can disrupt normalized unsustainable habits, of which we argue ontological politics play a vital role.

In the search for "worlds and knowledges otherwise" [36], and the potential for transgressive learning which result from the politics of their encounters, this research therefore aims to explore how concrete intercultural practices can lead to insights into how to imagine and practice the pluriverse in the sustainability arena. Considering that the pluriverse can be made visible by examining ontological conflicts (the unequal encounter between worlds) [37], or what has also been referred to as political ontology [20], our aims are to explore how this pluriverse might look like in sustainability practices, and the extent to which ontological encounters can lead to transgressive learning. It is important to address ontological encounters in the sustainability debate for three reasons. The first is that 
there is an increasing recognition that ontological predispositions play an important role in how people understand and engage with sustainability challenges $[6,38,39]$. With a country like Colombia managing to atypically balance a high Human Development Index (HDI), while maintaining a low ecological footprint [40] it is important to explore the ontological basis of this. The second reason is that when different visions of sustainability and the realities that enact them are played out in practice, their encounters lead to a politics where different realities interact and compete with one another [9]. Rather than romanticizing a "pluriverse" where everybody gets along, engaging with such "ontological politics" forces us to not only acknowledge the existence of different realities, but also the power plays within and between them which adds increasing complexity to already "wicked" challenges of sustainability [41]. This leads us to the third reason, which is that meetings between ontologies have the potential to not only be transformative in how we learn about the world around us [4], but also activate "transgressive" learning processes which challenge the status quo through action-oriented interventions [27]. By responding to the Call of the Mountain-the call for a more sustainable world-we will engage in the debates of ontological politics in practice, as well as providing some examples in which ontological encounters leads to a type of learning potentially "transgressive" in kind.

\section{Methodology: New Ethnography and the Voice of the Researcher}

In addressing the aims above, it is vital to employ a methodology which allows us to enter (to the extent it is possible) the pluriverse, and to critically represent the interactions which take place. Central to this methodology is the acknowledgment that research is never impartial but an assemblage with its own effects on the event researched comprising of researchers, data, methods and contexts [42]. This is in line with the increasing skepticism in the postmodern world regarding the objectivity of the researcher, the generalization of knowledge claims, and the realist agendas where the researcher is put above the subject and the method over the subject matter [43]. In keeping with the ontological turn, we have tried, as Viveiros de Castro advocates [44], taking seriously the things the people we study tell us, while acknowledging, at the same time, that we inevitably bring our own ontological assumptions into the research encounter. We have hence employed methods of "new ethnography" [45] where narrative is employed to communicate findings using the tools of storytelling. Specifically, this involves elements of auto-ethnography as a way of acknowledging the role of the researcher in voicing the results. Analytic auto-ethnography [46] involves three aspects which can be seen in our methods:

(1) We are full members of the researched group or setting: Participant observation was carried out by the first two authors who immersed themselves in the network studied (C.A.S.A. Colombia), where the first author gradually became actively involved in the organizing committee of $E l$ Llamado. Both authors have participated in several Llamados since 2011 and have carried out informal and semi-structured interviews during the Llamados of 2014 and 2015.

(2) We are visible in the resulting texts: As witnessed by the opening paragraph of this paper, and as will be seen in the first section of the results, narrative techniques are employed to generate "creative narratives shaped out of a writer's personal experiences within a culture and addressed to academic and public audiences" (p. 9). Employing personal voice also contributes to the idea that research is performative [47]. A good example of a monologue written in this way can be seen in the work of Mario Blaser who in his book Storytelling globalization from the Chaco and beyond [9] engages in knowledge practice grounded in a relational ontology, advocating a pluriverse where other forms of knowledge and ontologies are accepted.

(3) We are committed to developing theoretical understandings of broader social phenomena: As researchers the focus is on the role of enacting the pluriverse in activating transformative and transgressive learning processes which are been increasingly acknowledged as imperative in sustainability process for social change. 


\section{Enacting a Learning Pluriverse: The Collective Process of El Llamado}

"We are servants of this humanity, as souls we are all drops of the same sea, love is our nourishment to sprout. To be slighter than the grass and more tolerant than a tree, our heritage is humbleness."

(Yayati, Hare Krishna devotee from the community Varsana)

"We are the humanity that is sprouting, cells of the earth remembering, a joyful singing rainbow, to awaken all of mankind." (Tatiana, Ecovillager)

“We are 'taitas', 'mayores' y 'mamitas'-[names given to Indigenous elders, men and women respectively] -we receive the message from the mountain, and together we will construct a new tomorrow." (Camilo from the community Tal, Cundinamarca) (The above are verses written by participants during the 2015 event to contribute to the song written by the Misak youth Lorenzo Muelas Tombé.)

The gathering El Llamado began in 2006 when pioneers in the Colombian ecovillage movement gathered in the community Pachamama to share experiences in a family setting and explore ways to foster a social movement. An ecovillage can be defined as "a planetary knowledge community grounded in a holistic ontology and seeking to construct viable living systems as an alternative to the unsustainable legacy of modernity" [48] (p. 125). The gathering remained very much a small ecovillage affair until 2012, when the organizers came together with ecovillagers from different parts of Latin America and Spain to form the Council of Sustainable Settlements of Latin America (C.A.S.A.) with the vision of articulating a broad diversity of initiatives beyond the ecovillage realm around different ways of understanding and practicing sustainability.

As of today, C.A.S.A. Colombia has been building up the network with initiatives which exert "views of sustainability different from those of 'mainstream' [including the government] who see nature as a human resource ... but instead consider nature as an entity endowed with spirit, which the human being is caregiver, and with which we want to cultivate a deep spiritual relationship that involves changing our role in the world" (C.A.S.A. institutional documentation). This endeavor has led organizers and participants to immerse themselves in a process of assembling visions and practices of sustainability across many cultures through experiential learning, thus encountering all the challenges of such processes along the way.

In this section, we first provide an auto-ethnographic narrative as a way of presenting the transgressive learning experienced by the first author during El Llamado of 2015, in which she was a participant as well as an organizer. In the second part, we bring specific examples of ontological politics which surfaced during the two Llamados of 2014 and 2015, demonstrating further possibilities for transgressive learning through encounters of difference.

\subsection{A Glimpse into El Llamado de la Montaña, 2015}

"It is the 5 January 2015, and I am on the bus entering the Misak territory. Looking out the window I see a beautiful landscape full of rolling hills and mountains. I have seen them several times before, but this time they look different. What I know now about this territory and how it relates to its people has changed my perception of these mountains. They have become alive to me. With a little help from my imagination I see the hills as noses, the mountains as heads, breasts and legs, the small houses as eyes and the clouds as hair or beards, moving in the wind.

After arriving to the pueblo Silvia, it is time to walk up into the mountains along a beautiful river which leads to the Misak University. Curious faces follow me from the houses I pass by, and perhaps this is not strange as before me and behind me there are other 'backpackers' walking the same path as me. This is certainly not so common in what the Colombian government describe as an 'insecure and difficult region'. 
As I walk the final steps to the Misak University I reflect on my process of trying to understand the Misak peoples' relations to their territory, and on how these relations influence the way they think and act. How much will participants manage to understand in five days of co-existence?

Misunderstandings have been common in organizing El Llamado together with the Misak. After each visit I have always carried the feeling of not getting the whole picture of our relationship, and not being able to entirely explain these differences. During the few times I thought 'I got it', later events proved the contrary. It is not a question of language; it is a question of how our individual and collective worlds work and how we experience them differently. For example, while as an organizer I was more concerned about the logistics of food, accommodation, the scheduling of activities, and special guests, the main concerns of the Misak organizers were the possible harm to the energy of the territory and the fear/excitement of sharing their knowledge with us. They argued, for example, that after their medicine men consulted the territory, it was decided that the temascal (ritual sweat lodges from the Indigenous people of North American which are run by healers in every Llamado) where not possible to carry out during this version of El Llamado: "Our territory is of water and the temascal is a ritual of fire. If we carry it out here we can create an imbalance in nature and even wake up the volcanoes." (Misak organizer)

With all this in mind, I felt the pressure of my anxiety: How will these different worlds meet and connect? How are the relatively reserved Misak people going to face the numerous hugs and other physical contact that are the 'menu of the day' during every Llamado? How are other participants going to deal with all the rules and rituals surrounding the care of the Misak territory?

The first challenge I encountered was during the registration for the event when we had to ask women if they were going to be in their menstrual cycle during El Llamado. This was a shocking question for many, and difficult for me to ask. Even more shocking was the information that if they were in their cycle then they could not help in the kitchen or cross any streams of water, they had to have a special cleansing and harmonization ritual and they could not attend the highly anticipated Minga - the collective work party. The look on the faces of several of these urban-based women was of utter disbelief. Equality? Segregation? Discrimination? I tried to explain the complexity of this 'territorio despierto' (awakened territory) of the Misak people and make them feel positive about their situation. The network of 'women circles' had organized a special event just for the women with 'the moon' (as they call women in their menstrual cycles) where they could sit with the women elders from the territory to better understand the relation between their 'state' and the territory. Though perhaps not convinced, several of these women accepted the invitation and followed the instructions. It was satisfying when one of these women came to me in the lasts days of El Llamado to tell me that the highlight of her experience had been the circle of women. Through this experience she had been able to connect with her inner-self through the stories of other women. She dealt with personal issues and was able to grasp the opportunities and the magic of being a 'woman with the moon'. She also told me of learning practical things about sustainability, such as the option of using cloth pads or women cups instead of disposable pads, and about the importance of bringing feminine qualities (such as caring, emotions, and flexibility) into her job and everyday life.

Late in the afternoon, the cleansing of participants was programed. Participants were asked to sit in a horizontal line behind a group of medicine men who were 'speaking' to the territory. Without explanation, people accepted the situation and waited for something to happen. After two hours nothing had 'happened'. The medicine men stood gazing out into the mountains, whispering softly to the wind, while participants began to feel cold, tired and bored. Hare Krishna devotees started singing and people quickly joined in-songs about taking care of mother earth-as a means of lightening the mood as well as a means to join in the message of harmony with the territory. Well, the medicine men were not happy about this; they informed me that the noise and energy was making their job more difficult. Yet how could we stop the singing if this was the way people were dealing with such a foreign situation? Eventually a thick mist began descending from the 
mountains enveloping everyone, further decreasing the temperature and silencing the singing. Many participants, tired and cold, started leaving for their tents. At last, a medicine man explained that the mist was the actual cleansing. He brushed each person front and back with a branch soaked in water infused with medicinal plants. The ritual was over; the remaining people stumbled back to their tents in the dark, some confused, some contented, and most just ready for bed.

The next day, during the programed panel discussion on buen vivir (the good life), in which leaders of several Indigenous communities told their story of struggling to establish their good life against the 'development machine', I was thinking how far removed my personal story was from those experiences. When it was the turn for the ecovillage representative to speak I felt uneasy. I had lived for a period of time in the ecovillage of this representative, and after listening to all the stories of indigenous repression and resistance I wondered what the ecovillage world could contribute? Jorge, the ecovillager speaker, began by explaining the role of the mestizo of urban origin in bringing back sustainability in practice to mainstream society. He talked about our need to learn from native communities how to reconnect with place and nature, but also about day-to-day struggles of dealing with waste management, and the loss of spirituality and hope in youth. This was confirmed by the next speaker, the Colombian ex-senator Gloria Cuartas stating that we (the audience) need it to become 'the geography of hope' to heal this country in conflict, Colombia. I felt inspired again and more secure of what I could offer to others.

Part of my volunteer duties was to help in the kitchen, but when I arrived there was chaos. People were passing through the kitchen on the way to their tents; one group of people were chopping carrots, while others were singing and talking around the fire where the food was being cooked. I felt sorry for the woman in charge of the kitchen who appeared stressed with all the bustle. Together with other C.A.S.A. organizers we tried to organize the flow of people through the kitchen and asked the singers and those just hanging around to leave the kitchen. Suddenly I was stopped by the Misak mamita in charge of the kitchen who asked what I was doing. "I'm helping you organize the kitchen-you looked stressed" I replied. "No, no, no", she told me. "My kitchen is open for everyone, I like having people around; this is the Misak way. Everybody is welcome, all activity and learning starts from the 'fogon' (wood stove)—it is the heart of the community. I'm not stressed because of all the people, but because those who were supposed to come and help prepare the food have not arrived. I'm running late with the lunch!" I felt ashamed to have imposed my perception of a chaotic kitchen by assuming it was the same for everyone. And also frustrated with so much talk about showing love through serving the other, but so few people actually helping in the kitchen. So I stepped out of my organizing role, and joined a gossiping group of Misak women peeling potatoes and good naturedly teasing a Norwegian participant who was helping them and trying out words in their language. I sat down next to Gobinda, a Hare Krishna woman, who shared this reflection with me: "The Misak territory teaches us unity, order, expansion, and brotherhood. Look at the way they organize the kitchen tasks. I generally organize the kitchen of my community by having everything prepared at the same time ... five people are in charge of peeling potatoes, while three are in charge of chopping onions, and so on. Here it is different: we all sit and peel all the potatoes, then we all chop the onions... I interpret this as a teaching: is not only about getting the job done efficiently but being together-united in everything we do."

The day ended with the magical night in which Anthakarana, a family ecovillage of artists, performed what they call the ritual-theater, where they combine sustainability issues with rituals of different origins, which are carried out in interaction with the audience. They asked people to light the candle of the person beside them and to move together as a united group around the fire in the middle of the Misak University hall, calling out visions of how a new humanity could be. Faces of people began to light up with each candle, I saw Indigenous, afro, white, mestizo faces; I saw foreigners, locals, youth, children, elders, women and men. This was a powerful experience with over 300 candle-lit people moving together. At the beginning I felt concern with so many candles around me: my hair! - I thought. I started to think of all the things that could go wrong. But after a while, my mind 
relaxed and I concentrated in following the movement of people around me ... I started to feel trust, 'we are all taking care of each other' I told myself. In that moment I felt like the room became the whole world with all its diversity, I felt that the fire was also dancing amongst us ... I started to feel joy in my heart as I was able to feel connected with all forms of beings, all holding one similar wish: to live in a more sustainable and harmonious world. I felt like I a large family surrounded me. Perhaps the collective process of acknowledging multiplicity is the first step in building any long-term sustainability, I thought to myself, and trusting the process the second step. This new insight transformed the way I now see sustainability issues. [49]

\subsection{Ontological Hotspots and Their Dissonance}

As we have seen in the previous section, the diversity of participants and types of activities carried out during El Llamado bring about a number of encounters of difference. What we will now look into are two "ontological hotspots," which we use to denote a situation or activity which was commonly approached very differently by participants of El Llamado. Such hotspots created a high degree of dissonance between participants with different ontologies, providing the potential for ingrained ways of "being" in world to be shaken up a little.

\subsubsection{Hare Krishna "House Rules" and the Rigidity of Ontologies}

El Llamado of 2014 was held in the ecovillage Varsana, Cundinamarca, which is a sacred Hare Krishna monastery along the Vrinda line of practice. Under the hierarchical guidance of their guru Swami B.A. Paramadvaiti, devotees follow the teachings of the sacred Vedic scriptures, in which the ultimate goal is service to God. This all-encompassing philosophy is witnessed through the practices of simple living, serving others and constant prayer and meditation through the repetition of the Hare Krishna mantra. The Hare Krishna community has a hierarchical organization, in which the spiritual guide plays a strong role in teaching Vedic scriptures to its followers and in making decisions. Consequently, the "house rules" of the monastery are well defined and strict: nudity, sexual relations, consumption of meat, the use of any kind of stimulants (including coffee, alcohol and cigarettes) and even campfires are strictly prohibited in the sacred grounds of the monastery. Although nudity and the use of drugs and alcohol are also prohibited by the organization of El Llamado, "power plants" (plants used for rituals which have the property to induce other states of consciousness) such as tobacco and coca leaves used for rituals and sexual relations in private places are allowed, as well as consumption of coffee. Furthermore, fire is a strong symbol for several C.A.S.A. members, who consider it a sacred living entity who plays a vital role in mambeos-ceremonial conversations around the fire. Elders light a sacred campfire during the opening ceremony of every Llamado, and is kept going during the entire event, day and night.

During the organization of the event it became clear that emphasis would have to be placed on respecting the "house rules" in Varsana, while negotiating ways for participants to express their own ideas of sacredness. At the early stage of the event Hare Krishna organizers and participants found ways of negotiating some of these rules. The Hare Krishna hosts compromised by allowing the mambeo campfire in the monastery grounds, as they understood its spiritual purpose, but under the condition that it was only to be lit and maintained by Indigenous elders. A group of coffee lovers met every morning outside the property grounds of Varsana to share coffee prepared on a camping stove, while another group hiked to a nearby hill to smoke cigarettes. These early morning activities were for some the means to joyfully bear the rigidity of the house rules and express freedom of choice, as some conversations around the coffee conveyed. Nonetheless, a few participants were not able to follow the restriction on campfires and decided to start their own campfire in the middle of social activities to the surprise of devotees and C.A.S.A. organizers. Arguing that the fire was their means of connecting to the earth and of celebrating life, they refused to put it out after a polite request from a Hare Krishna organizer, and it took the heated words of C.A.S.A. organizers and other participants for the fire to be removed. 
Further discord grew out of the Hare Krishna philosophy and practices around food, and what is to them the sacred art of cooking. As Nitia from Varsana argued, "Food for us, as we offer it, is more a spiritual food. Of course is also for the body but is more to feed the spirit." The preparation and consumption of food is based on the ahimsa principle, which in Sanskrit denotes non-violence and compassion, and is related to karma. In accordance with strict vegetarianism, Hare Krishnas have a strict etiquette in the kitchen and for serving food. One needs to be clean, bathed, have good oral hygiene and one cannot taste food or eat anything during cooking or serving (this includes tasting the food before it is served). An important part of El Llamado, however, is the "loving service" in which participants are asked to volunteer in communal tasks, such as helping in the kitchen. Unlike the Misak who see the kitchen and the fire as a meeting and learning point, the Hare Krishnas found it challenging to have participants not of the faith aid in food preparation and cooking. How could they be sure people were properly bathed and clean? Would they be imparting the right reverence to the food? Problematic situations arose when some participant arrived to the kitchen chewing coca leaves, which was perceived as eating by devotees and hence the participants were initially refused entry. Participants argued, however, that in their ontology chewing coca leaves was sacred and a form of meditation and connecting with the "great spirit" and were very disappointed at not being allowed to help. In another example, a participant who was a professional chef was most disappointed when his specially brought cooking knives were refused entry to the kitchen as they had previously been in contact with meat, and thus defied the principle of ahimsa. This participant expressed his disappointment, as according to him food making was one of the few activities he saw the possibility of sharing and connecting with Hare Krishnas. (In a later conversation with a Hare Krishna devotee it was remarked that there are in fact cleansing ceremonies which can be undertaken to cleanse utensils which have been in contact with meat. For whatever reason, such a ceremony was not suggested or carried out at the time.)

Adding to this discomfort of the rules of the kitchen was the actual practice of vegetarianism. The organization of C.A.S.A. programs vegetarian menus for El Llamado as many members are vegetarian and to lower costs of the event, while at the same time providing opportunities for meat-eaters to experience different types of foods. However, many participants do not consider themselves vegetarian. Several claim that animals are part of the web of life, together with humans and plants, thus respect towards them is shown by the way you breed them and by the compassionate way you kill them, thanking the animals for their sacrifice and ensuring no waste. On the other hand, some strict vegetarians (which were not only devotees) argued that what one eats is directly related to one's level of spirituality, implying that vegetarians have a higher level of conscience than those who consume meat. This ontological difference became a dissonance during El Llamado and got as far as the awkward situation of having some Mamos (highly acclaimed spiritual leaders from Indigenous groups of the region Sierra Nevada of Colombia), excusing themselves for consuming wild meat which they argue is needed to enrich their diets high up in the mountains where they live. Moreover, when writing the final declaration which would represent the voice of all participants of the gathering, the C.A.S.A. organization refused to include vegetarianism in the text as it did not represent all C.A.S.A. members. This created tensions and until today a joint declaration has not been signed.

Unable to resolve these tensions the Hare Krishna organizers became increasingly stressed. Devotees called an urgent meeting with their spiritual leader Swami B.A. Paramadvaiti who arrived during the event, to ask for guidance. A devotee shared the defining outcome of the meeting: "Swami Paramadvaiti told us that the main idea was that people should feel good and accepted in Varsana, for them not to feel in such a strange place that they would not want to get involved. He told us to be flexible if the intentions of others were good and were carried out in a loving manner." This message relaxed devotees who became more flexible and tolerant to the transgressions of participants. Since the 2014 Llamado, the involvement of the Hare Krishnas has grown, with Hare Krishna facilitators and participants in the 2015 Llamado in the Misak University. Although devotees helped in the kitchen and joined all activities, they also quietly prepared their own food in their tents when conditions in the kitchen did not meet their requirements. 


\subsubsection{Learning about Power Relations through Ontological Encounters}

El Llamado of 2015 was held at the Misak University in the territory of Guambía. As a non-formal university, its purpose is to prepare young leaders to work in their territory in accordance to their ancient wisdom and customs. According to the Misak cosmology, their territory is a living, breathing entity, and it is important to exert close relationships to it through their traditions and customs. For example, as the Misak people originated from the highland lagoons of their territory, they consider these areas sacred and it is where their ancestors guard the "wisdom of all times". Consequently, they devote up to $70 \%$ of their territory to preserve the lagoons and paramos (cloud forests) in which the water of their territory is born (the other $30 \%$ they inhabit).

As a knowledge community attempting to bring back traditional customs and practices which are being lost due to a history of colonization and now modernity, the Misak University saw the possibility of forging an alliance with C.A.S.A. as a means of promoting territorial discussions, albeit within a context of deep suspicion by several students and teachers towards outsiders. (Based on a history of marginalization through government policies, academics writing about their traditions without their approval, and economic challenges of globalization, many Misak see the possibility of having their knowledge and resources exploited by outsiders who visit their territory.) Miscommunication caused a major rift already before El Llamado began. Unlike the hierarchical decision making process of the Hare Krishna community Varsana, the Misak university has a more horizontal (though multilevel) platform. The director of the University is the governor of the Indigenous territory Guambía, and decisions are made together with academic directors, coordinators, and to a degree, students. The C.A.S.A. organization committee followed protocols by asking permission to carry out El Llamado from the governor and the university coordinators. However, this permission was given before students were informed. This caused discontent among some students who stood up against El Llamado arguing that it represented an outsider agenda to "steal" their knowledge and impose western ways on the community. C.A.S.A. organizers attempted to mend the situation by explaining the philosophy of El Llamado directly to students, emphasizing that all activities would be respectful to their territory and traditions, and that they were invited to share only as much as they felt comfortable with.

Although some students decided not to attend, others embraced the event, eager to exert their knowledge by ensuring that the meaningful practices and rituals of the Misak people were carried out in the proper way. Protecting these relations, the desire of students to take charge and "protect" their territory led to several incidents. One of the students (a skeptical opponent to the event taking place) took the opportunity to practice his studies into Misak medicine and rituals, and letting people believe he was an expert, conducted a cleansing ritual to harmonize the energy of the C.A.S.A. organizers with that of the territory. Afterwards, organizers were told that because the ritual was carried out during the day (and not the night) it did not count, and that a Misak elder with more expertise would have to repeat it (this was the cleansing ritual described in the previous section).

Another important point within the Misak ontology is the relationship with el abuelo fuego (grandfather fire). It is around el fogón (the hearth fire) that from an early age knowledge is imparted by family and elders. In keeping with this tradition, a central hearth fire is continuously burning in the main University hall, around which many discussions are held. During the event, Misak organizers decided to appoint one of their teachers to maintain the central fire, which involved nurturing it by placing the logs in a special way, and periodically feeding the fire with tobacco and coca leafs.

It is not clear why the Misak organizers chose this person to take care of such important Misak tradition, as he himself was not a Misak person born in the territory but of urban origin. Nevertheless, he was a knowledgeable academic, who knew not only about the Misak traditions but also had contact with other Indigenous groups of Colombia. This task gave great authority to this person who meticulously controlled the fire and those helping him. However, as the days passed by, the situation became an increasing source of tension as the teacher became rude and impatient with those around him, reprimanding those who were not "following" the Misak ways. On the energetic level, non-Misak elders began talking of a strong negative energy pervading the event, and hence the need 
for neutralizing the situation at the energetic level. C.A.S.A. organizers and participants tried to remain open minded and respectful of the teacher's appointed role, but tensions became unbearable when his actions increasingly became offensive and divisive. Misak organizers were informed of the situation and all parties agreed to talk around another fire to understand what was happening. After a long session where the teacher kept verbally attacking the event and its participants, one of the highest ranked Misak organizers stood up and stamping the floor with his staff, stated: "I am Misak, I am my territory, and I only accept the positive. What I have seen here [in this event] are only positive things for my territory." Everyone stood up in support of this statement, and although asked to stay, the teacher left the event. With this episode, the role of elders as keepers of harmony at the energetic and spiritual levels was better understood by C.A.S.A. organizers, who were unaware of the struggles at this invisible level. Furthermore, during post-event evaluation and reflection, a learning point amongst organizers was the extent to which roles and positions appointed during El Llamado give power to people, thus they must be well understood and only given if strictly necessary, as power struggles can cause a disharmonized environment not conducive for learning.

\section{Discussion}

"One feels that nobody is right here, I mean, nobody owns the truth ... each person is a link within the chain we are all part of." [50]

The above results sections have attempted to display the ontological politics that play out in enacting an "environmentalism of everyday life" and what it would mean to experience an intercultural gathering from the perspective of a pluriverse. By bringing the reader through a day in El Llamado, and highlighting two ontological "hotspots" of potential transgressive learning, as well as the experiential clashes of the first author in her personal journey through El Llamado, we have witnessed something which at least hints at the encounters between different worlds. What we want to bring to the discussion table now is the extent to which we can talk about a pluriverse in practice, and how engaging with these worlds can lead to transgressive learning towards more sustainable everyday living.

Reading through the results section it becomes clear that our modern day anthropocentric distinctions between humans and nature do not articulate well with what takes place in intercultural events such as El Llamado. Thus non-human actors such el abuelo fuego (grandfather fire) and the territory as a sentient being, we maintain, cannot be seen as entities belonging to the realm of "Nature" while human actors (Hare Krishnas, ecovillagers and so on) belong to the domain of "Culture". These divides, as Latour [51] has shown, are problematic because, in practice, different categories of the so-called "natural" and the so-called "cultural" are heavily entwined. In order to side-step the rather arbitrary division between "Nature" and "Culture" we resorted to the notion of "ontology". We find it important to note though that "ontology" is not just another word for "culture", as some anthropologists have recently suggested [52]. To us, taking the stance that ontology is another word for culture means taking on board unwarranted notions of multiculturalism and a host of accompanying dichotomies such as those between Nature/Culture, facts/beliefs or truth/superstition [26]. Instead, we have adopted a "multinaturalist" stance $[22,26]$, that is, the understanding that there exist many kinds of Natures - possibly as many as there are cultures. This alternative frame, apparent in many Indigenous Amazonian philosophies [53-56], but also elsewhere [8,57-62] has consequences for the understanding of "Nature" and demands a renewed attention to ontological politics. In adopting such a "multinaturalist" or "pluriversal" stance we have taken the concerns of our research subjects seriously, providing an account of ontological politics which we believe the protagonists of our story would not disagree with. In other words, our account was not unduly shaped by our analytical and ontological concepts; rather, it was fashioned by "what we found" - what is perhaps the strongest point of the ontological turn [63]. This was clearly not an easy task: no matter how we talk about wanting to be open minded and inclusive to other ontologies, engaging with them in practice can be extremely difficult and, to put it in Helen Verran's [64] words, thoroughly disconcerting yet extremely valuable for critical reflection. Although a "cleansing" for the territory may be necessary for harmonizing 
energy between people and place, a four-hour long ritual with no information outside in the cold is cumbersome. The same goes, of course, for those who partake in El Llamado: not to be able to participate in most activities because one has "the moon", or not being able to cook with knives brought from home because they have been in contact with meat is challenging to say the least-and inevitably involves an ontological politics.

In the context of socio-ecological problems, ontological politics such as those described above tend to stay below the radar, or are misrepresented. At best, they would seem to be only indirectly related to environmental change; at worst, they could be presented as essentialist discourses or "New Age" ruminations. In order to more fully grasp what goes on during the different Llamados, we argue that it is expedient to attend to the ontological premises (i.e., different realities) upon which C.A.S.A.'s gatherings are based. Only then can we put in proper perspective that what participants are actually engaged in. This is not a plea to romanticize these gatherings, but rather an appeal to focus on crucial ontological politics. Attending to the participants' alternative way of measuring and evidencing "environmental problems" is important for two reasons. First, because it feeds the way in which they imagine and shape their responses to it; second, and for practical reasons, because understanding how they do so may help shape transgressive learning in crucial transition processes.

It is important to note here that we as researchers actively participate in an ontological politics as well. The choices we make (that is: writing in the way we write) are not only of an epistemological kind but involve, at the same time, moral, ethical and political issues. In fact, and here we follow Jensen [65], one could state that the things we bring to the fore through our writing (such as sustainability and learning) "collapse into ontology" and that, in so doing, we are effectively performing our own ontology-thus intervening in an ongoing ontological politics around these "things".

Despite its unique characteristics, we believe that our case study helps to shed light on more general processes that shape alternative and non-modern ways of dealing with complex socio-ecological problems. As we have shown, in order to shape an "environmentalism of everyday life" it is expedient for those involved to exercise some form of ontological politesse. Communicative disjunctures-dialogues of the deaf-could, we think, be turned into constructive encounters if ontological differences were explicitly allowed to enter the negotiation room. The problem in this "learning to play with strangers" [66] is that one first needs to let go of the idea that debates about the environment are wars fed by epistemological politics (in the sense of settling the issue of what party can best measure and represent the environment), but rather attempts to arrive at agreement by way of an ontological politics [18] or a "cosmopolitics" that works as a cure for the "malady of tolerance" [67]. The proposal here is that decisions about how to deal with socio-ecological problems must, one way or another, take place in the presence of those who will bear their consequences. Like in our case, this requires acknowledging that "complex socio-ecological problems" carry different meanings for different people in different places. In the literature there are modest (yet sufficient) and workable examples of people negotiating and working across ontologies [62,68-71]; for two fascinating accounts of ontological dovetailing in scientific institutions see Cussins [72] and Mol [61].

In general, however, most individuals and communities (including indigenous communities) have rather singular ontologies, which in a globalizing world with shrinking ecological boundaries they are forced do compromise or even abandon. During El Llamado we argue, though, that to some extent transgressive learning is taking place through these ontological encounters, which address the complexity of socio-ecological challenges. Having managed to transgress her moral boundaries on equality and male/female relations, the participant on "her moon" managed to engage and reflect on her own femininity not only in the context of the event, but also in her own day-to-day life. This was made possible through a woman's circle where these issues were discussed and rituals took place. The situation with the teacher also brought up learning points on the power of traditions and unseen forces, and the necessity of valuing energetic levels in resolving these tensions. Compare these examples to the situation of the participant whose knives were denied access in what we can see as an "ontological impasse" where little positive learning has taken place. As one Hare Krishna 
devotee noted in retrospect, a ritual cleansing of the knives and a reflexive talk around the principles of ahimsa could have been carried out. If this had occurred together with the participant then a two-way conversation could have taken place, perhaps coming to some form of understanding and compromise. On a more collective scale, the ritualistic cleansing would have been an opportune time for the Misak to facilitate "affective flows" [42] of feelings and emotions into the non-human realm, explaining to participants the harmonization of energetic levels through the forces of nature, and really creating an "experience" which would cross boundaries of reason and meaning. Instead, at best, the cleansing maintained the mystical quality of people with a very different ontology, and, at worst, created or maintained a disconnection and a barrier to entering the realities of the Misak. It is important to emphasis here that although we speak of a "Misak ontology" it would be a delusion to think that the ontology of Others can be fully apprehended or described. For an interesting debate about how to approach Others' ontologies see Blaser [9] and Jensen [65].)

The role and power of those that mediate between different worlds brings us to the second point. As noted about the pluriverse in section two, there is no one logic that can mediate between the power-saturated realities of different worlds [73]. This means that issues of power arise when negotiating these different worlds as there is no one person who is "right". However, each respective ontology has representatives of power. In the hierarchical ontology of the Hare Krishna, the guru holds ultimate power through the interpretation of the ancient Vedic scripts, and it was to him devotees came with their concerns over the transgressions of non-Hare Krishna participants. It was a positive sign to the devotees, participants in El Llamado, and possibilities for greater sustainability processes that a leader of such a religious community had the capacity to be flexible in the rules of the community and was able to grasp the type of inclusive social tissue being created beyond a single "truth". In the community of the Misak University, however, power is held by University directors and students, and wielded through the elders and medicine men who are knowledgeable of the customs and traditions of the community and have the power to communicate with the territory. It is ultimately they who can communicate with other entities through rituals such as the mambeo and the cleansing, and decide what is allowed and what is not.

This points to the difficulties of learning-based interventions overcoming structural power, whether they come from the one truth of modernity, or from other realities which make up the pluriverse. As the example of the teacher also demonstrated, the capacity to understand (or at least represent) an ontology can give tremendous power, and his inflexibility and aggressive stance in upholding what were for him Misak traditions created tensions and disrupted relations between the organizers and participants. Consequently, when we talk about a decolonization of knowledge where "nobody owns the truth", we must be prepared for a strong degree of inflexibility in ontologies, and ever-present power negotiations between those who represent each ontology. It is then interesting that unlike the top-down conflict resolution of the Hare Krishna community (without dialogue between the parties) Misak and C.A.S.A. organizers were able to sit down around the fire to discuss the conflict with the teacher. For one of the Taitas to stand up against the "negative energy" of the teacher demonstrates a negotiation of power between representatives, though unfortunately after this negotiation the teacher left and there was no opportunity to continue a reflection on the situation which could have resulted in deeper and perhaps more transgressive learning for all parties. Nevertheless, for C.A.S.A. organizers this became a source of learning in understanding the invisible power struggles that emerge when enacting the pluriverse.

So what does engaging with the pluriverse tell us about facing the sustainability challenges of our time? Well clearly a "world in which many worlds fit" is an exciting but rather utopian idea, at least at this point in time. Accustomed as most of us to the natural world being around us-instead of us being part of it-accepting different constellations of human-nature relations is a long and complicated process. Although there may well have been transgressive "moments" for participants and organizers, where structural barriers became visible through ontological encounters, for it to be called transgressive "learning" implies a long-term process in which structures are not just made visible, 
but also broken, and to an extent surpassed. It is perhaps better to think of a transition towards more inclusive understandings of other worlds and their sustainability practices. This does not necessarily mean a harmony between different ways of being sustainable, but at least a conversation as equal partners. El Llamado represents an attempt at such a transition through a tangible engagement with the pluriverse whereby, for example, participating in a cleansing, a sacred march and in a collective effort to "plant water" participants have the potential to gain insights into different enacted realities where harmonizing foreign energy and planting trees increases the territory's satisfaction and thus creates water in the mountain's lagoons through which the ancestors guard the territory's wisdom. At the same time, however, the initial inflexibility of the Hare Krishna community clearly created a lot stress for the devotees and divides between participants and the host community, as well as the divide, in the Misak case, between those who can communicate with "earth beings" and hence represent and control that ontology in its relation to others.

It is therefore worth ending this discussion with what we can view as both an inspirational as well as perhaps naive message from the Hare Krishna guru and the Misak Taita: only the positive is welcome-if actions are carried out based on love and good intentions then we should be flexible enough to allow for their manifestations and embrace the challenge that they bring to us as stimulants to improve our own ways. Although this philosophy contributed to the reduction of tensions in both the previous examples, it also raises the uneasy issue of the extent to which we should compromise what we believe in in the name of a tolerant and inclusive social tissue, especially if we should consider other ontologies inherently unsustainable and unfair. Vegetarianism is an example of an issue in which no compromise could be made at the level of writing a common manifesto. With the complexities of different ontologies, it could be useful to keep in mind the idea that our understandings with other ontologies will only ever be "partial connections" [25] in which different ontologies are entangled with one another, and which we will never really "get".

Hence, a question which is left for further research is how can we make a better use of these "partial connections" to engage the pluriverse in transitions towards a more sustainable and inclusive future? This, of course, begs the question of how to productively engage with ontological conflicts entailing "radical difference"; that is, conflicts in which interlocutors are unwilling to collaborate in bringing about transgressive learning processes. One way to go here would be, as Bonelli [74] proposes, to try to create a greater awareness (amongst conflicting parties) of their own particular ontological presuppositions so that room can be made for ontological diplomacy through "pragmatic encounters" [75].

\section{Conclusions}

Engaging with the pluriverse confronts us with differences in other people and in ourselves. Such confrontation or mirroring, and the frictions and dissonances it creates, has the potential to make us rethink our own norms, values and stubborn everyday routines and assumptions. This means leaving our comfort zones and experiencing other worlds where territories are literally alive, where food being prepared cannot be tasted out of respect for serving God, or where women "on their moon" have such strong and sacred energy that they cannot participate in communal activities. In a context of entrenched unsustainable practices which most of us partake in, such experiential learning can be transgressive to the extent that we really manage to cross the boundary of our own entrenched lifestyles and embrace not just the idea that we are different, but also what this means in practice.

It is important to note, however, that this process of boundary crossing and mirroring is not easy. As our example of El Llamado de la Montaña has hopefully demonstrated, organizing, facilitating and participating in intercultuscaled upral settings which are generative to transgressive learning is a challenging task. Diversity in itself is no panacea and often leads to misunderstanding and even conflicts, which must be addressed if reflexivity and learning to live together through difference and conviviality are to take place. Ontologies are not just very complicated; they may be more or less rigid 
and saturated with power, and negotiating them in the name of crossing boundaries towards different worlds will require new types of knowledge, skills and methodologies for the future.

It is also worth noting that not all people are willing to engage and experience the pluriverse as it means leaving the safety of a single "truth" and predictability of one's own comfort zone. This is a challenge for the pluriverse which implies participation by many actors. During El Llamado there is a pronounced absence of mainstream politicians, government officials and businessmen which gives the event a feeling of alternativeness, and a sense of disarticulation with wider society. This remains a great challenge for El Llamado, as well as society at large as the mainstream is also part of the pluriverse, and articulation with these groups is essential for transitioning towards truly deep changes in society.

Finally, we would like to point to the productive possibilities inherent to our case. Transgressive learning involves continuous negotiations between different worlds and realities. In these negotiations, worlds engage with one another-thus becoming sensitive to those ontological disjunctures that may lead to misunderstandings. Transgressive learning entails (as a minimum) an effort to translate different but oftentimes partially connected realities-a translation akin to the method of "controlled equivocation" proposed by Viveiros de Castro [26]. While difficult, transgressive learning demands an active awareness of other ways of being in the world. Insensitivity to this, as our case demonstrates, may result in a failure to learn. Openness to the possibility to be "moved over" [76] or, in our terms, being open to ontological politics thus has practical and political value as it allows for the (cosmo)political task of shaping the "environmentalism of everyday life" as a process of ontological dialogue. To be sure, the solution of complex socio-ecological problems requires the nurturing of diplomacy: the capacity to move in and relate ways of knowing and being that partly overflow one another, yet without a-priori assuming one to be superior. We therefore wish to stress ontological difference as a positive, productive capacity; a "useful complication" that stimulates thinking and reflection. Transgressive learning cherishes this difference, and renders it productive: it allows for trying out ways to find or create a "middle ground" [77] in the pluriverse.

Acknowledgments: Funding for this study has been provided by the Administrative Department of Science, Technology and Innovation of Colombia, COLCIENCIAS. Special acknowledgments to the C.A.S.A. network Colombia and its organizing team for collaborating in this research and for their commitment in building social laboratories for sustainability around Colombia through volunteer work.

Author Contributions: All authors helped conceive and design the research for this paper, while the first author Martha Chaves carried out the main fieldwork with the aid of the second author Thomas Macintyre. The first two authors also analyzed the data and wrote the paper, but with substantial contributions from the last two authors, Gerard Verschoor and Arjen Wals, in terms of contributing analysis tools, providing constructive feedback, and copyediting expertise.

Conflicts of Interest: The authors declare no conflict of interest.

\section{Abbreviations}

The following abbreviation is used in this manuscript:

C.A.S.A. Consejo de Asentamientos Sustentables de las Américas (the Council of Human Settlements of Latin America)

\section{References}

1. Council of Women Elders of Colombia. Available online: http://consejodeabuelas.wix.com/ consejodeabuelas (accessed on 20 December 2016).

2. Parr, A. Hijacking Sustainability; The MIT Press Cambridge: Cambridge, MA, USA, 2009.

3. Wals, A.E.J. Beyond Unreasonable Doubt: Education and Learning for Socio-Ecological Sustainability in the Anthropocene. Available online: http://library.wur.nl/WebQuery/clc/redes/2103430 (accessed on 20 December 2016).

4. Wals, A.E.J. Learning Our Way to Sustainability. J. Educ. Sustain. Dev. 2011, 5, 177-186. [CrossRef]

5. Chaves, M. Answering the "Call of the Mountain": Co-Creating Sustainability through Networks of Change in Colombia. Ph.D. Thesis, Wageningen University, Wegeningen, The Netherlands, 2016.

6. Mcmichael, P. Rethinking Land Grab Ontology. Rural Sociol. 2014, 79, 34-55. [CrossRef] 
7. Gudynas, E. Buen vivir: Germinando alternativas al desarrollo. Am. Lat. Mov. 2011, 462, 1-20. (In Spanish)

8. De La Cadena, M. Indigenous cosmopolitics in the andes: Conceptual reflections beyond "politics". Cult. Anthropol. 2010, 25, 334-370. [CrossRef]

9. Blaser, M. Storytelling Globalization from the Chaco and beyond; Duke University Press: Durham/London, UK, 2010.

10. Escobar, A. Sustainability: Design for the pluriverse. Development 2011, 54, 137-140. [CrossRef]

11. Martin, P.M.; Glesne, C. From the Global Village to the Pluriverse? “Other" Ethics for Cross-Cultural Qualitative Research. Ethics Place Environ. 2002, 5, 205-221. [CrossRef]

12. Grosfoguel, R. Decolonizing Post-Colonial Studies and Paradigms of Political Economy: Transmodernity, Decolonial Thinking, and Global Coloniality. Transmodernity 2011, 1, 1-36.

13. Escobar, A. Encountering Development: The Making and Unmaking of the Third World; Princeton University Press: Princeton, NJ, USA, 2011.

14. Wals, A.E.J.; Jickling, B. "Sustainability” in higher education. Int. J. Sustain. High. Educ. 2002, 3, $221-232$. [CrossRef]

15. C.A.S.A. Colombia. Available online: http://www.casacontinental.org/ (accessed on 20 December 2016). (In Spanish)

16. Schlosberg, D.; Coles, R. The new environmentalism of everyday life: Sustainability, material flows and movements. Contemp. Polit. Theory 2016, 15, 160-181. [CrossRef]

17. Holbraad, M.; Pedersen, M.; de Castro, E. The Politics of Ontology: Anthropological Positions. Available online: https:/ / culanth.org/fieldsights/462-the-politics-of-ontology-anthropological-positions (accessed on 18 May 2016).

18. Mol, A. Ontological politics. A word and some questions. Sociol. Rev. 1999, 47, 74-89.

19. Blaser, M. Ontology and indigeneity: On the political ontology of heterogeneous assemblages. Cult. Geogr. 2014, 21, 49-58. [CrossRef]

20. Blaser, M. Political Ontology: Cultural Studies without "cultures"? Cult. Stud. 2009, 23, 873-896. [CrossRef]

21. Palecek, M.; Risjord, M. Relativism and the Ontological Turn within Anthropology. Philos. Soc. Sci. 2012, 43, 3-23. [CrossRef]

22. De Castro, E.V. Cosmological Deixis and Amerindian Perspectivism. J. R. Anthropol. Inst. 1998, 4, 469-488. [CrossRef]

23. Bacchi, C.L. Strategic interventions and ontological politics: Research as political practice. In Engaging with Carol Bacchi: Strategic Interventions and Exchanges; University of Adelaide Press: Adelaide, Australia, 2012; pp. 141-156.

24. Latour, B. Whose Cosmos, which Cosmopolitics? Common Knowl. 2004, 10, 450-462. [CrossRef]

25. Strathern, M. Partial Connections; Rowman \& Littlefield: Savage, MD, USA, 1991.

26. De Castro, E.V. Perspectival anthropology and the method of controlled equivocation. Tipiti J. Soc. Anthropol. Lowl. S. Am. 2004, 2, 2-22.

27. Lotz-Sisitka, H.; Wals, A.E.; Kronlid, D.; McGarry, D. Transformative, transgressive social learning: Rethinking higher education pedagogy in times of systemic global dysfunction. Curr. Opin. Environ. Sustain. 2015, 16, 73-80. [CrossRef]

28. Peters, M.A.; Wals, A.E.J. Transgressive learning in times of global systemic dysfunction: Interview with Arjen Wals. Open Rev. Educ. Res. 2016, 3, 179-189. [CrossRef]

29. Transgressive Learning. Available online: http://transgressivelearning.org/ (accessed on 20 December 2016).

30. Mezirow, J. Transformative Learning: Theory to Practice. New Dir. Adult Contin. Educ. 1997, 1997, 5-12. [CrossRef]

31. De Lissovoy, N. Decolonial pedagogy and the ethics of the global. Discourse Stud. Cult. Political Educ. 2010, 31, 279-293. [CrossRef]

32. Freire, P. Pedagogy of the Oppressed; Continuum: New York, NY, USA, 1970.

33. Geels, F.W. Ontologies, socio-technical transitions (to sustainability), and the multi-level perspective. Res. Policy 2010, 39, 495-510. [CrossRef]

34. Wals, A.; Heymann, F. Learning on the edge: Exploring the change potential of conflict in social learning for sustainable living. In Educating for a Culture of Social and Ecological Peace; Wenden, A., Ed.; State University of New York Press: New York, NY, USA, 2004; pp. 123-145. 
35. Sol, J.; Beers, P.J.; Wals, A.E.J. Social learning in regional innovation networks: Trust, commitment and reframing as emergent properties of interaction. J. Clean. Prod. 2013, 49, 35-43. [CrossRef]

36. Escobar, A. Beyond the Third World: Imperial globality, global coloniality and anti-globalisation social movements. Third World Q. 2004, 25, 207-230. [CrossRef]

37. Escobar, A. Más allá del desarrollo: Postdesarrollo y transiciones hacia el pluriverso. Rev. Antropol. Soc. 2012, 21, 23-62. (In Spainish) [CrossRef]

38. UNESCO (United Nations Educational Scientific and Cultural Orgaianization). Education for People and Planet: Creating Sustainable Futures for All; UNESCO: Paris, France, 2016; pp. 1-535.

39. Wijesooriya, C.; Heales, J.; McCoy, S. Multi-Dimensional Views for Sustainability: Ontological Approach. Available online: http:/ /aisel.aisnet.org/cgi/viewcontent.cgi?article=1194\&context=amcis2015 (accessed on 20 December 2016).

40. Global Footprint Network. Available online: http://www.footprintnetwork.org/en/index.php/GFN/page/ trends/colombia/ (accessed on 15 September 2016).

41. Australian Public Service Commission. Tackling Wicked Problems: A Public Policy Perspective; Australian Government: Canberra, Australia, 2007.

42. Fox, N.J.; Alldred, P. New materialist social inquiry: Designs, methods and the research-assemblage. Int. J. Soc. Res. Methodol. 2015, 18, 399-414. [CrossRef]

43. Spry, T. Performing Autoethnography: An Embodied Methodological Praxis. Qual. Inq. 2001, 7, $706-732$. [CrossRef]

44. De Castro, E.V. Who is afraid of the ontological wolf? Some comments on a recent anthropological debate. Camb. J. Anthropol. 2015, 33, 2-17.

45. Goodall, H.L. Writing the New Ethnography; AltaMira Press: Walnut Creek, CA, USA, 2000.

46. Anderson, L. Analytic Autoethnography. J. Contemp. Ethnogr. 2006, 35, 373-395. [CrossRef]

47. Law, J. Seeing like a survey. Cult. Sociol. 2009, 3, 239-256. [CrossRef]

48. Litfin, K. Reinventing the future: The global ecovillage movement as a holistic knowledge community. In Environmental Governance: Power and Knowledge in a Local-Global World; Kütting, G., Lipschutz, R.D., Eds.; The MIT Press: Cambridge, MA, USA, 2009.

49. Chaves, M.; Cauca Territory, Colombia. Personal communication, 2016.

50. Anonymous Participant; El Llamado de la Montaña, Cauca Territory, Colombia. Personal communication, 2014.

51. Latour, B. We Have Never Been Modern; Harvard University Press: Cambridge, MA, USA, 1993.

52. Carrithers, M.; Candea, M.; Sykes, K.; Holbraad, M.; Venkatesan, S. Ontology Is Just Another Word for Culture: Motion Tabled at the 2008 Meeting of the Group for Debates in Anthropological Theory, University of Manchester. Crit. Anthropol. 2010, 30, 152-200. [CrossRef]

53. Arhem, K. The cosmic food web. In Nature and Society: Anthropological Perspectives; Routledge: London, UK, 1996; pp. 185-204.

54. Descola, P. In the Society of Nature: A Native Ecology in Amazonia; Cambridge University Press: Cambridge, MA, USA, 1994.

55. Reichel-Dolmatoff, G. Cosmology as Ecological Analysis: A View from the Rain Forest. Man 1976, 11, 307-318. [CrossRef]

56. Rival, L. The Growth of Family Trees: Understanding Huaorani Perceptions of the Forest. Man 1993, 28, 635-652. [CrossRef]

57. Wagner, R. The Invention of Culture; University of Chicago Press: Chicago, IL, USA, 1981.

58. Verran, H. Re-imagining land ownership in Australia. Postcolonial Stud. 1998, 1, 237-254. [CrossRef]

59. Bonelli, C. Ontological disorders: Nightmares, psychotropic drugs and evil spirits in southern Chile. Anthropol. Theory 2013, 12, 407-426. [CrossRef]

60. Muller, S. Co-motion: Making space to care for country. Geoforum 2014, 54, 132-141. [CrossRef]

61. Mol, A. The Body Multiple: Ontology in Medical Practice; Duke University Press: Durham, NC, USA; London, UK, 2002.

62. Umans, L.; Arce, A. Fixing rural development cooperation? Not in situations involving blurring and fluidity. J. Rural Stud. 2014, 34, 337-344. [CrossRef]

63. Henare, A.; Holbraad, M.; Wastell, S. Thinking through Things: Theorising Artefacts Ethnographically; Routledge: London, UK; New York, NY, USA, 2007.

64. Verran, H. Science and an African Logic; University of Chicago Press: Chicago, IL, USA, 2001. 
65. Jensen, C.B. Practical Ontologies. Available online: https://culanth.org/fieldsights/466-practical-ontologies (accessed on 20 December 2016).

66. Haraway, D. When Species Meet; University of Minnesota Press: Minneapolis, MN, USA, 2008.

67. Stengers, I. Cosmopolitics I; University of Minnesota Press: Minneapolis, MN, USA, 2010.

68. Castleden, H.; Garvin, T.; Nation, H.F. “Hishuk Tsawak” (Everything Is One/Connected): A Huu-ay-aht Worldview for Seeing Forestry in British Columbia, Canada. Soc. Nat. Resour. 2009, 22, 789-804. [CrossRef]

69. Echeverri, J.A. Territory as body and territory as nature: Intercultural dialogue? In The Land Within: Indigenous Territory and the Perception of Environment; Surrallés, A., Hierro, P.G., Eds.; Centraltrykkeriet Skive: Copenhagen, Denmark, 2005; pp. 230-247.

70. Verran, H. A Postcolonial Moment in Science Studies: Alternative Firing Regimes of Environmental Scientists and Aboriginal Landowners. Soc. Stud. Sci. 2002, 32, 729-762. [CrossRef]

71. Gombay, N. "Poaching"-What's in a name? Debates about law, property, and protection in the context of settler colonialism. Geoforum 2014, 55, 1-12.

72. Cussins, C. Ontological Choreography: Agency through Objectification in Infertility Clinics. Soc. Stud. Sci. 2016, 26, 575-610. [CrossRef]

73. Law, J. What's Wrong with a One-World World. Available online: http://www.heterogeneities.net/ publications/Law2011WhatsWrongWithAOneWorldWorld.pdf (accessed on 10 April 2016).

74. Bonelli, C. To see that which cannot be seen: Ontological differences and public health policies in Southern Chile. J. R. Anthropol. Inst. 2015, 21, 872-891. [CrossRef]

75. De Almeida, M.B. Caipora e outros conflitos ontológicos. Rev. Antropol. UFSCar 2013, 5, 7-28.

76. Kohn, E. How Forests Think: Towards an Anthropology beyond the Human; University of California Press: Berkeley, CA, USA, 2013.

77. White, R. The Middle Ground: Indians, Empires, and Republics in the Great Lakes Region, 1650-1815; Cambridge University Press: New York, NY, USA, 1991.

(C) 2016 by the authors; licensee MDPI, Basel, Switzerland. This article is an open access article distributed under the terms and conditions of the Creative Commons Attribution (CC-BY) license (http:/ / creativecommons.org/licenses/by/4.0/). 